\title{
Interrogating the Applicability of the Integrated Water Resources Management (IWRM) Model
}

\author{
Itai Offat Manyanhaire ${ }^{1} \&$ Leonora Nyaruwata $^{2}$ \\ ${ }^{1}$ The Department of Geography and Environmental Studies, the Zimbabwe Open University, Zimbabwe \\ ${ }^{2}$ The Zimbabwe Open University, Zimbabwe \\ Correspondence: Itai Offat Manyanhaire, Department of Geography and Environmental Studies, Faculty of \\ Science and Technology, the Zimbabwe Open University 12th Floor Century Towers, No. 45 Samora Machel \\ Avenue Box Mp1119 Mount Pleasant Harare, Zimbabwe. Tel: 263-4-793-002. E-mail: \\ offatmanyanhaire@gmail.com; offatmanya@yahoo.com
}

Received: September 1, 2013 Accepted: January 16, 2014 Online Published: February 20, 2014

doi:10.5539/enrr.v4n1p130ＵRL: http://dx.doi.org/10.5539/enrr.v4n1p130

\begin{abstract}
The global response to the increasing water scarcity in the last twenty years has been water policy reforms directed towards the implementation of integrated water resources management (IWRM). IWRM was expected to promote the coordinated development and management of water, land and related resources in order to maximize the resultant economic and social welfare in an equitable manner without compromising the sustainability of vital ecosystems. This paper interrogates the applicability of the model using literature sources and personal experiences with the model. Literature at global level on the issue of IWRM has been split between optimistic peddlers of the model and the pessimists that in recent years have critically questioned the suitability of the model as a master prescription for varied and complex global river catchments catchments. The paper traces also the complexity of the definition of IWRM and the related implementation limitations of the model. The paper further demonstrates how this model of water resources management is unlikely to work for different social and environmental contexts. The management should focus on addressing real water problems affecting communities rather than wasting resources on the philosophical complexities of the model.
\end{abstract}

Keywords: integrated, interrogating, model, applicability, management, water

\section{Introduction}

Water is life. It is ubiquitous, in constant movement, changing quantities and qualities within different locations of the global and catchment space. It is a cross cutting resource that drives our social and economic life styles. To this end improving the way water is managed unlocks great potential and value for equity in water use and the participation of different water users at catchment level. The global trend in the last twenty years has been the preference for the heavily funded Integrated Water Resources Management (IWRM) model as a prescription for all water issues in different social and water management contexts. The premise for the push for reforms in the water sector has been that water management has been sectoral and reductionist for too long and that there was need to better coordinate the management of different water resources management components (ground water and surface water) between various sectors and actors, across links in the water sector (Butterworth et al., 2010).

Saravanan, McDonald and Mollinga (2008) in one of their working papers branded IWRM as the most popular development ideologies since the middle of the 20th Century. They go on to acknowledge that the experience of integrated water resources management generated both problems and controversies in both developed and developing world. The problems were to integrate land and water, integrate natural territorial river basins with administrative organisations, and more importantly, political participation and behavioural consideration in the planning process (Wescoat, 1984). This paper is premised on the applicability of the IWRM model focusing mainly on its definition, evolution and implementation challenges. The paper will further interrogate the inappropriateness and inadequacies of the IWRM model in resolving catchment based water management problems in different biophysical and socio-economic contexts. The IWRM has been described by Beveridge and Monsees (2012) as being prone to the faults of development assistance in general including the imposition of models emanating from developed countries, short termisms and lack of resources. The discussion that unfolds 
on this uses an analysis of publications on water resources management, documents of the Global Water Partnership and personal experience with global movements in water resources management.

\section{Defining Integrated Water Resources Management}

According to the Global Water Partnership (GWP, 2000) IWRM is "a process which promotes the coordinated development and management of water, land and related resources in order to maximise the resultant economic and social welfare in an equitable manner without compromising the sustainability of vital ecosystems".

Cardwell, Cole, Cartwright and Martin (2006) unpacked the definition of IWRM by first defining the words integrated, water, resources and management. This approach, from face value, is interesting and simplifies the complex model. However, in reality, this approach extends the confusion surrounding the theory and practice of the model. According to their argument integration means the unification of the various components that make up a water system through management and attainment of set objectives. Management is a complex social process that functions through set institutions, related social networks and a web of physical aspects within the catchment of concern (Bandaragoda, 2005). Similarly in the human system, integration is required between demand and supply, across various water use sectors, among various stakeholders and in numerous socioeconomic considerations (Bandaragoda, 2002). The definition defies precision given the broad physical and human attributes that must be integrated.

To further clarify the concept it is important to review the various types of definitions as they are used in different contexts and to analyse the constitution of the word definition. According to Copi (1986) the five purposes of definitions are: to increase vocabulary, to eliminate ambiguity, to reduce vagueness, to explain theoretically and to influence attitudes. The definition of IWRM uses a complex system of words. Complex systems have roots in the complexity theory (Gill, 1993). It is a process in which action and information affect each other. A negative feedback relationship can cause a system to become stagnant and unable to adapt to suddenly changing situations (Vennix, 1996). A positive feedback on the other hand, describes a chain of increasingly self reinforcing processes. This introduces uncertainty in the river catchment system. Complex systems imply that we cannot have perfect knowledge and therefore cannot calculate the performance of for example social systems in their complexity (Cilliers, 2005). Our knowledge of the complex water systems is therefore, spatially and temporally limited. Thus, we are incapacitated to make purely objective claims given the mosaic of uncertainties that make up the water management system at the catchment level. Strategic uncertainties arise due to the multiplicity of stakeholders that are involved in water management at catchment level.

The words like equitable and vital ecosystems in the context they are used here contrast the logic of removing ambiguity in the definition of IWRM. The definition can be described as essentially vague as the limits of the applicability of the IWRM model are illusive. The issue of equity may have complex social dimensions. For example in Zimbabwe legal access to water was through water rights given to those who had title to land (white community) whilst those who did not have titles (black peasants) did not have these rights unless they were given communal rights like irrigation schemes. Thus, water reforms were in part directed towards redressing these racially based equity issues. But this did not guarantee gender equity issues and access to water resources. There are so many borderline cases associated with words like coordinated development, land and related resources and vital ecosystems. The theoretical explanations of the definition do not provide scientifically adequate and useful characterization of the objects to which it is applied. The fifth characteristic best suits the characterization of the definition of integrated water resources management. It is a definition intended to change attitudes and approaches of water resources management. The definition is broad and all-encompassing but with little practical resonance on the present or on the future water management (Biswas, 2008). This type of criticism coming from the founding members of the model demonstrates the frustrations associated with the use of the model as a strategy to manage water resources. The key threads from the definition include; maximise, economic and social welfare, equitable, sustainability and vital ecosystems. These concepts need some clarifications before one can present its major characteristics. The challenge with 'maximise' has to do with choosing of the parameters to be maximised and using what methodology to select them (Biswas, 2008). This concept underplays the complexity of the issues involved in the space time changes of a particular catchment and in particular the mosaic of experts that should be involved.

The definition refers to equity in water resources management but this poses the greatest threat to water availability in its varying spatial changes at catchment level. How does the issue of equity take centre stage when the model is driven by water experts whose roots are found outside the realm of the indigenous technical knowledge framework of the catchments to be managed? Similarly, the use of the word sustainability in the 
definition presents challenges to water management. The concept of sustainability on its own is a rhetoric that confuses its protagonists. The definition is precisely a concoction of vague and confusing concepts which makes it difficult to interpret and to implement. Biswas (2008) alleges that its popularity has to do with its vagueness since people can continue to do what they had done before or are doing at present. The form of the phenomenon has changed but the content remains the same because perhaps the change drivers remain stuck in their old technical practices of water resources management. Morphological changes of a phenomenon are characteristically defining qualitative changes to the behaviours of the individuals in charge of the water resource management process. The definition is wordy and though it gives the impression of a complex system the management processes for such systems are often not well defined. The institutions to implement such a complex model are usually erroneously described as lacking capacity. Is this a game to divert from the real issues of water management? Why then committing resources to change water management without the full understanding of the issues at hand? Is it adequate to argue that old systems of water management have failed and thus we should embark on global scale water management reforms?

The definition also makes reference to vital ecosystem which prompts one to interrogate whether there are other systems that are not vital and how these can be classified? The concept of integration make it more complex and confusing as there are so many aspects of the river catchment that need to be integrated, the stakeholders and their various functions, the ecosystems, surface water, ground water, government agencies, legal and policy frameworks and many others. The list is endless and thus the model could be more problematic to define. Some of the limits of the concepts will be explained later on in the discussion. In the developing world the converts to this have been attracted more by money associated with researching in this area rather than the passion for water management. There is already an excess baggage of graduates trained in IWRM who are misplaced and have not found a home in the water fraternity. The current trend is to link the issue of climate change with IWRM in a more nauseating format as it attracts the efforts of specialists and the peddlers of the vulnerability and adaptation theories. Is IWRM controlling the threats of climate change? If not, why the euphoria about the issue of climate change and IWRM? Is this a way of seeking sympathy from those that have the money and channel it towards the poor communities of the south? But what is the source of this model that has standardized water management at the global scale? Merrey (2007) took a more radical position when he called for the priests of IWRM to abandon ship and come up with new approaches to water resources management. Whilst acknowledging it as the systems approach framework it was no longer a feasible approach to water management. Why would this attract controversies among the believers in the ecosystem approaches and its application to water management?

\section{The Evolution of the IWRM Model}

Since the emergency of environmental sustainability movement in the 1970s, and the holding of the first 1992 Earth Summit in Rio de Janeiro in Brazil, questions pertaining to water management have received considerable attention (Loris, 2008). Attaining sustainability in water resources management became a priority objective for the global water community and national governance though with limited knowledge of the best practice of water resources management. The IWRM model was preferred as the most appropriate framework for attaining sustainability in the water sector. In Asia particularly Nepal, India and Malaysia the model has been regarded as the panacea to water related problems (Mohile, 2005; Onta, 2005; Abdullah, 2005). Contrary, Jonch-Clausen (2004) and the Global water Partnerships (GWP, 2003) recognize that the IWRM framework should not be seen as a universal blueprint or perspective model and that it is evolutionary and always changing and cannot be a panacea for poverty reduction but can facilitate management of water resources and water services in ways that will help to reduce poverty. How then are we supposed to manage this evolutionary and illusive phenomenon? Despite the concerns on its applicability in the varying catchments most countries have implemented water policy reforms that incorporate the principles of IWRM. One may have to cautiously acknowledge that during the time immediately after the Rio Earth Summit in 1992 capital resources and intellectual force was driven towards attaining sustainable development as a major priority for economic and environmental planning. The role of water resources in this projected development is indisputable. Thus, the 'novel' IWRM model was to improve efficiency in water use, promote equity in access to water and to achieve sustainability (Butterworth, 2010). Is sustainable development achievable in a world of sharp contrasts in economic and socio-political contexts? A world where there are widening gaps between the rich and the poor countries. The availability of water in various regions of the world is part to the differentiation in spatial economic development. Water resources continue to be at the centre of global water related conflicts which are likely to escalate in the near and remote future. Given this realisation water resources management deserve a critical analysis and continual improvement of systems so that the illusive dream of sustainability in the water sector is attained.

It is imperative that one comments on the origin and evolution of the concept of integrated water resources 
management, its principles and practice at global level. However, caution must be exercised as the debate on its origin transcend generations, political and social contexts that it may require a full paper on its own. This paper only provides some highlights so that the discussion of the model is viewed in the perspective of current practices in water management. There is confusion in literature with regard to the origins and evolution of IWRM. Biswas (2008) views the approach as institutionalised and integrated over centuries whilst Swatuk (2002 ) thinks it emerged in the 1990s and has since then shaped water reforms, in among other regions Southern Africa. There is evidence in literature that this model started in the north with specific cases from the Tennessee Valley Authority in the United States of America (Tortajada, 2005) and in Valencia in Spain as early as the 10th century (Rahaman \& Varis, 2005). IWRM became a dominant paradigm in the 1990s. Molle (2006) suggests that while in many respects it is "old wine in new bottles," there are important changes too: issues that had been seen as minor in the past became more prominent, for example, pollution, aquifer mining, and the need to involve stakeholders more actively. There are also arguments that link the birth of the model to Mal de Plata Conference of 1977 which set the platform for an internationally coordinated approach to IWRM. This international coordination of the management of water resources was strengthened by the Dublin Conference in 1992. The Dublin Conference (International Conference on Water and Environment, 1992) set out four guiding principles associated with water use, that, water is a finite and vulnerable resource; participatory approach is essential; the role of women is important; and water needs to be managed as an economic good. The Rio Conference (U.N. Conference on Environment and Development, 1992) and its Agenda 21 emphasised the focus on a number of water management programmes, the first of which was integrated water resources management. The Agenda 21 identified three key objectives for integrated water resources management: priority for satisfying basic human and ecosystem requirements, river basin as the basis for managing water resources, and preparation of national action and sustainable water use programmes by the year 2000.The question is then why adopting old styles of water management as current standard procedures?

Biswas (2008) further interrogates why an old concept suddenly became popular in the 1990s, to an extent that some people and institutions even considered it to be the 'holy grail of water management?' Two major reasons were advanced from this question. The first reason is the simplicity of the model in terms of its appeal to water professionals. IWRM gives hope to the notion of comprehensive and holistic approach in water resources management simplifying the complexity of the catchment as a water resource management unit. The second reason and the major driver of the model has been the availability of donor funds for research and training in water resources management. The prominence of such approaches hinges on the willingness of the donor community to support research in IWRM and the establishment of institutions that manage the process. The recycled model has thus, reached its peak basing on the donor capacity to keep the bandwagon rolling with little change in the practice of water allocation and management and it is dawning on water professionals that there is no visible progress. Water management is not an exception from the recycling of ideas occurring in other disciplines and sectors of the society. In this regard IWRM can be viewed as a postmodernism strategy that recognises that efficiency and effectiveness in water resources management can be attained through the use of a decentralised approach that puts human beings and the environment as key water users. It should be noted that social and economic developments have a central role in shaping thinking in the water sector like what happens in other spheres of life. Does phylosophising water management solve the problems of water scarcity and pollution?

The theory of liberalisation dominates scientific thinking in the post bipolar world through repackaging of old ideas that the modernists had earlier on regarded as backward and unworkable. Liberalisation refers to the removal of centralised controls of water resources management and makes its management more inclusive, broad based and participatory. It is assumed in this argument a participatory approach involves water users and their roles in decision making at catchment level. That is putting the intended users of water resources at the centre of water management and decision making. Earlier societies have often thrived on localised participation and decisions for the management of water and other resources though in what could be called rudimentary and primitive ways in the eyes of the protagonists modernisation. Modernisation, as assumed in this debate, entails the transition from a traditional society that is in essence an agrarian society to one that is based on trade and industry and characterised by diversity of opinions and centres of power. Why then advocating for a water management system that best identifies with localised administration of water resources? Community involvement in resource management has always been a characteristic feature of African communities. Arguably, the 'primitive societies' and their behaviours lived sustainably within their environments. It is time for those bankrolling the model and those avid believers of the model to ask questions of validity and applicability of the model. Why would practitioners abandon water management approaches that have worked for centuries and run on the IWRM gravy train? Perhaps old styles had become boring and mechanistic. Has the inevitable progressive 
decline in water availability in some regions pushed the so called water specialists to rethink about old styles of water management? Are legal reforms to accommodate IWRM a panacea to water problems in the world? The discussion on this line of thought would require a full interrogation and is not the subject of this paper.

The philosophy of IWRM currently drives water management thinking at global scale due mainly to the absence of a viable option within the context of sustainable development. A good example is the Zimbabwean water policy reforms where catchment and subcatchment councils replaced the centralised form of water management that was based on water rights. This master solution for all has attracted criticisms as frustration builds including among the revered protagonists of the philosophy like Biswas (2008). Clausen (2004), for example, argues that the approach should suit the country contexts and that there should not be one 'size fit all approach'. Is this feasible when the north is commanding the process and the south complying in an assumed beneficial partnership in water resources management? How applicable is this model in volatile political contexts? This will certainly deserve an international relations approach to discuss the meaning of these partnerships in the context of water management. The discussions in this paper revolve around the applicability of the approach through a meta-analysis of some of the rich record of literature that exists on IWRM. The debate emerging out of the seemingly increase of critical reviews of the model would require a long term comparative study of different water management contexts and its relevance to improving the management of water resources at local, national and global level. It is not within the scope of this paper to discuss all the issues pertaining to the use of the model but to give pointers towards the improvement of water management systems and to operate outside the box. The key question in the following subsection has to do with the paradox of implementing such a complex and confused model. It should be realized that naming this a model is not semantics but because it captures only the salient features of a complex river catchment. Elsewhere in literature it is named a strategy, a management system and so forth. However, a model remains a model and it can never be the perfect reality.

\section{What Are the Principles of Integrated Water Resources Management?}

There is a tendency in literature to argue that the principles explained below have their roots in the Dublin International Conference on Water and the Environment (1992). These familiar and virtually universally recognised principles are:

- Freshwater is a finite and vulnerable resource, essential to sustain life, development and the environment.

- Water development and management should be based on a participatory approach, involving users, planners and policy makers at all levels.

- Women play a central role in the provision, management and safeguarding of water.

- Water has an economic value in all its competing uses and should be recognised as an economic good.

These are some of the critical principles buttressing the IWRM model and in themselves complex and difficult to achieve in countries of the South where the institutions have no capacity and are poorly organised. A great part of the resources are spent on institutional reforms at the expense of actual mitigation and adaption to climate change. To better understand these principles and the paradox of IWRM it is important to examine some of their implications. It is important to recognise that water is finite and vulnerable. The spatial variations of river catchments at the local and international scales make water resources susceptible to environmental changes and a limiting factor to development. In view of this principle one is prompted to question the applicability of the principle in contexts where the water resource stock is continuously declining. It is not adequate to recognise the vulnerability of the resource to human induced environmental changes but to limit the degradation of the resource itself. With the rate of development and the levels of greediness at the global scale the deterioration of water quality remains a thorny in the flesh for the global community.

The second principle advocates for a participatory approach to water resources management. While the issue of participation has been recognised as being at the core of IWRM a common criticism has been its lack of people centeredness (Butterworth et al., 2010). The lack of concern for the people, especially the poor and marginalised (Merrey et al., 2005) is a recurring gripe against the concept (Butterworth et al., 2010). In essence participation in water resources management has largely been treated as a formality and dominated by local politicians rather than it being a real inclusive process driven from the bottom. That is stakeholder participation in water resources management has not promoted sustainability in the use of the resource as decision making continues to be driven through old styles and habits. One would hasten to ask, who are the stakeholders? What are their roles in the management of water resources? Is the involvement of stakeholders in water resources management adequate to achieve sustainability? What is the rationale for the involvement of stakeholders in water resources management when the resource continues to dwindle in stocks and environmental conditions are changing rapidly? The 
human population continues to increase and so are the associated water consumption levels.

The third principle makes reference to the issue of the centrality of women in water resources management. Perhaps other schools of thought advocate for a gender sensitive type of principle that should capture issues of gender mainstreaming in water resources management. It is, in essence, more of recognition of the idea that upholds the critical position of women within a water management framework. How far have the various states that have adopted the IWRM model gone towards attaining gender sensitive water management protocols? Does the composition of the institutions established to manage IWRM reflect the implementation of this principle? In deed women are central to water resources management but does that make water management sustainable?

The fourth principle makes reference to the economic value of water. This is in contrast to the social value of the resource. Water is generally believed to be a free resource that every human being must have access to without economic restrictions imposed on it. It is a natural gift from God. Recognition of the economic value of water confirms the centrality of the user pays principle as applied to natural resources management. However, not all citizens have the capacity to pay for the value of water particularly in the urban settings of the developing world. Does the recognition of the economic value of water help in attaining sustainability in water resources management? If so, why is water stock declining, creating spaces of critical water shortages? In view of the complexity of issues to be understood when applying IWRM model authors like Cardwell et al. (2005) propose that integration takes place along at least four axes. That is, spatial integration, objective integration, institutional integration, and temporal integration.

This framework provides the impetus for further interrogation of the model and its application. The spatial integration axis whilst geographically interesting does not provide the entire compelx network of issues to be integrated within this scope as nature in itself is dynamic and ever-changing. The human component has gaps in knowledge with regard to physical attributes of the catchment that control the availability of surface and groundwater flows. Reference to objective integration of the physical and human aspects of a catchment is on its on a mammoth task to achieve since there are so many human related activities to be integrated in circumstances where the drivers of IWRM have limited knowledge of the content and application of the model. Institutions, particularly in the African context, are weak and easily manipulated by the politicians. This will make sustainability in water resources management a futile exercise. The temporal axis as explained by Cardwell et al. (2005) recognises the dynamic nature of the issues to be dealt with at the catchment level. Circumstances are changing faster than the created institutions can cope. How then can we achieve sustainability in water resources management? Is the adoption and irrational application of the IWRM model a workable approach?

\section{How Do We Implement IWRM?}

The IWRM framework proposes a holistic approach that encompasses the spatial, social, participatory, administrative, organisational and sustainability aspects of water. What has this 'new' water management paradigm done to the water sector? The next question should be how does this favoured model deals with the issue of water scarcity in the world where the climate is changing and water utilisation increasing? How does the introduction of a more cumbersome water management strategy deals with the issue of climate change and its impact on rainfall quantities? These questions are difficult to answer in the context of IWRM since this is a learning process where water practitioners continue to encounter problems. This subsection discusses the implementation framework for IWRM. As the Global Water Partnership puts it:

"IWRM is a challenge to conventional practices, attitudes and professional certainties. It confronts entrenched sectoral interests and requires that the water resource is managed holistically for the benefit of all. No one pretends that meeting the IWRM challenge will be easy but it is vital that a start is made now to avert the burgeoning crisis."

The implementation framework for IWRM is as illustrated in Figure 1 below: 


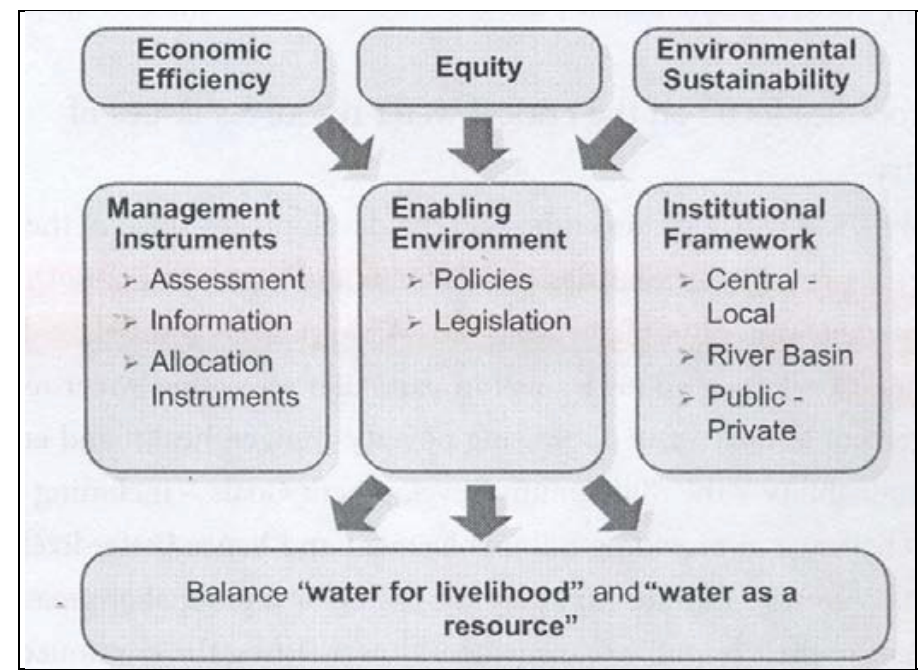

Figure 1. The three pillars of IWRM. Source: Jonch-Clausen (2004)

IWRM entail an amalgam of issues that are difficult to resolve in the short to long-term. Unfortunately, while much lip service has been given to this concept in recent years most of the published works on the subject are somewhat general or a continuum of earlier "Business as usual" approaches with trendier label of IWRM (Biswas, 2008). If this concept is to work at local and international levels water managers and professionals have to address complex real life puzzles in water management. Failure to address these complex issues will see the concept fading thrown into the dustbin of history with no vivid footprints.

Attempts to reform the legal and policy frameworks for water resources management in different regions of the world has been described as costly and time consuming by Butterworth et al. (2010). Catchment agencies are struggling to establish legitimacy in view of limited capacities. Lankford and Hepworth (2010) contrasted the level of capacities in Tanzania with those in the United kingdom and question why the approach is more or less the same in each country. Many authors attest to the fact that IWRM has been implemented as a relatively standard package (Butterworth et al., 2010; Shah \& van Koppen, 2006; Warner et al., 2009; Biswas, 2008). Mollinga (2006) described IWRM as a concept in search of a constituency as it is not locally rooted. Each management strategy adopted enforces among the users determined types of social relationships in relation to water utilisation with impacts that may hinder implementation of water policy. Perhaps the problems of water management are hinged on a clear understanding of how the social networks within catchments influence on the effective implementation of water policy. Human beings relate to the environment in various forms whose bearing is manifested in deferent signals that seem to elude the water managers. The nature of water resources research has been such that the focus is on what had already transpired and the current scenario. While this is important for water use and management forecast the approaches used tend to limit themselves to quantitative techniques with limited exploration of the social and policy perspectives to the issues. In pursuance of such approaches, management strategies have shifted from purely technical approaches in the past where the trained water professionals had the major say in water planning and decision making with limited inclusion of the water users at catchment level to the integrated water resources management.

In trying to address the issue of water reforms in Southern Africa for example the premise has been that sectoral water approaches have failed and they needed an overhaul since the resource was depleting fast whilst water related conflicts were increasing (Latham, 2002). Thus, an examination of the governance of water resources is worthwhile, as there is a water governance crisis in the world (Global Water Partnership, 2000). Literature on governance of natural resources that fall into the category of multiple use common pool resources, such as water, has highlighted the criticalness of putting in place clear governance structures and mechanisms in relation to the utilisation of the resource. Perhaps the most important issue to emerge from the debate by stakeholders over the last several years was the need to move away from a rigid and centralised system of water allocation by government to one where users have greater control over water and its management. The process has been driven by the perception that greater equity in access to and development of water resources was not only desirable but also necessary in the national interest.

In the process of correcting historical imbalances IWRM has generated new dimensions in water problems 
including issues of access to the resource, local participation in water resources planning and allocation, the issue of gender equality with reference to water and the environmental requirements of the water resource, the socio-economic value of water and above all the scarcity of water in the global scale due to the influence of climate change and increasing and competing demands for water. Whilst, conventional water resources management in most countries used the water rights system attached to land ownership the recent water sector reforms have favoured an integrated water resources management approach as the major driver for attaining sustainability in the water sector. In this regard the water sector reforms in Southern Africa and other parts of the world have been influenced by the IWRM approach as the most ideal in resolving issues of water allocation, planning and availability. This paper interrogates some of these water sector reforms and how these have changed the practice and relationships in water management.

With growing population and limited water resources, there is an increasing need worldwide to manage water resources better. This is especially true when all or nearly all water resources in a basin are allocated to various users. To this regard policy decisions are usually made to improve the management of water resources particularly so to resolve situations of scarcity. The concept of IWRM though proved to be a recycled (Biswas, 2008) one became the most popular with international donors and thus, policy transformations that took place in the 1990s were influenced by this type of thinking. The IWRM paradigm was expected to fulfill the demand for environmental sustainability which is equally complex and vague in definition and practice. It is important to take note of the close association between sustainable development and the goals of IWRM.

The sustainability agenda has reinvigorated attempts to better manage the water environment through appropriate policy making and integrated planning strategies (Loris, 2008). The meaning of sustainable water management has changed from simply meeting quantitative water demands to concerns about water quality and to the integration of spatial and temporal scales of multidimensional water issues. The translation of sustainability principles from theory to practice of water resources management has often been contentious and essentially inconclusive business particularly because of the difficulties in breaking the link between economic growth and water demand and the reluctance to incorporate issues of fairness and community involvement into decision making process (Syme \& Nacarrow, 2006).

The water policy reforms in Zimbabwe like the rest of the world were premised on the use of hydrological boundaries in water resources management, decentralisation of water management, stakeholder participation and the treatment of water as an economic good (GWP, 2000; Mtisi, 2011). These essential principles of IWRM were crafted into the new laws with the anticipation to redress colonial injustices in the water sector (Matinenga,1999; Bolding et al., 1998) and at the same time to embrace the global discourse of IWRM which was actively promoted in Southern Africa by the GWP (Mtisi, 2011). The literature, preceding the year 2000, profusely argued for the adoption of the IWRM model as a means to achieve sustainability in complex catchment systems. Inception assessments for the IWRM were for the paradigm with little regard for the complexity and uniqueness of the different hydrological zones in the country and how this would impact on sustainability in water resources management. The appropriateness of adopting such a nebulous concept in different socio-economic contexts remains a mystery and the resultant impacts of the reforms raise a number of queries with regard to the impact of these policy reforms. The 1998 Water Act, in Zimbabwe for example, was promulgated to improve equity in access to water and the sustainable management of the resource. However, contrary to expectations, the success of IWRM model has received limited examination. The following subsection discusses some of the ,limitations of the IWRM model.

\section{The Limits of IWRM}

Merrey (2007) provides a candid description of what the IWRM "dogma" can do and what it cannot do. To summarize the argument so far: as a systems framework for explaining and researching the interconnectedness of people, ecosystems, hydrology, and the like in a river basin, IWRM is a very useful broad and fuzzy intellectual tool. As a framework for educating professionals and laypersons it is also very useful. IWRM is also a useful way of creating a community of professional researchers and practitioners who have a set of shared values (van der Zaag, 2005). But many people also perceive IWRM as an important guide or blueprint for implementation in developing countries. However, there is a growing critical literature questioning this faith in IWRM. The implementation of the model has social, economic, biophysical and political challenges. The social aspects of a river basin have not been fully conceptualised as these are overshadowed by the technocratic type of thinking that continue to dominate water resources management. Each river basin has a social context that needs clear understanding and how this can be exploited to improve water resources management. Water is a basic human right and as such must be managed in a coordinated manner with shared responsibilities towards the development of new water sources and its allocation within a catchment. Whilst there is much agitation towards 
the adoption of IWRM and in particular to increase the participation of water users, people continue to be irresponsible with the environmental aspects of water management. Loris (2008) notes the skepticism particularly in developing countries regarding the impact of IWRM on the social and economic demands and lasting environmental degradation (Swatuk, 2005). Legal transformation in itself is not adequate to address issues of equity and social responsibility in water management. It should be remembered that all the legal changes have been based on the principles of IWRM. It amounts to legalising controversy under the guise of sustainable water resources management. Little attention has been given to operational problems and political disputes on the ground. How do you separate the issue of water management from political rhetoric? Politicians are known to take advantage of water projects to gunner support from their constituencies.

The environmental benefits are hinged on the use of the ecosystem approach in water resources management. However, the representation of the ecosystem within catchment councils is not feasible although there has been reference to environmental flow requirements when considering water utilisation. It remains to be seen how water users at the catchment level recognise the importance of environmental flows. The agricultural sector continues to be a major user of water and source of non-point pollution. The disruption of the allocation of water resources to this sector has profound consequences on agro-economies. However, such allocation must be integrative and inclusive when making decisions for water allocation. Similarly with regard to water supply and sanitation the issue of water security should be central if water poverty levels are to be addressed. It is hypothesised that at the local level improved integration of water resource management could lead to greatly reduced costs of providing domestic water services. The details of the limitations and the proposed way forward are summarized by Butterworth et al. (2010). These authors, whilst they recognise the limitations of the IWRM model they seem to believe that there is a better way of implementing the confusing model at a local level. They believe, it appears, in a more pragmatic approach to the implementation of the model.

\section{Conclusions and Policy Implications}

The IWRM model has been adopted as the standard for water management in the last twenty years. It has been argued for and assumed the most suitable approach that can help nations to attain sustainability in water resources management and this has been heavily funded and marketed. IWRM adopts the ecosystems approach to water management and provides a viable framework for a holistic analysis and management of water resources at river catchment level. However, the model has been viewed as having epistemological problems regarding its meaning and interpretation. The key principles of the model recognises that water is finite, the need for participation of water users, gender balance and water as an economic good. These are equally complex and difficult to achieve in reality.

The key threads from the definition include; maximise, economic and social welfare, equitable, sustainability and vital ecosystems. These concepts need some clarifications before one can present its major characteristics. The challenge with "maximize" has to do with choosing of the parameters to be maximised and using what methodology to select them. This concept underplays the complexity of the issues involved in the space time changes of a particular catchment and in particular the mosaic of experts that should be involved. Economic and social welfare is grossly broad and constitute a complex in the practice of water management. It is about the human being and the wave of activities that support life. The theoretical delimitations of such a network of issues are complex and difficult to conceptualise.

It has been argued in the discussion that its popularity has to do with its vagueness since people can continue to do what they had done before or are doing at present. The form of the phenomenon has changed but the content remains the same because perhaps the change drivers remain stuck in their old technical practices of water resources management.

The finite and vulnerable nature of water leads to competing demands and conflicts among users and yet many still lack access to adequate water supply for basic needs. The resultant effect is one of demand outstripping supply and posing challenges to sustainable development a problem that confronted the sectoral approaches that preceded the IWRM model. The most compelling scenario with particular reference to urbanised catchments is the pressure exerted on the limited resource by a variety of characteristically hungry and irresponsible users that aim to satisfy their own water requirements at the expense of sharing the resource at basin level. The response to the increasing water scarcity has been water policy reforms through the implementation of integrated water resources management. The overall expectations from such water policy reforms are positive behavioural changes with reference to water utilisation. Little attention has been given in literature on the catchment as a unit of water management and a complex that represents an intersection of legal frameworks for other natural resources particularly the land. 
Water conflicts have been the order of the day putting to test the applicability of the model of IWRM. This makes sustainable planning of water resources difficult since its availability from one catchment to the other is highly variable. Solutions to water problems depend not only on water availability, but also on many other factors, among which are prevailing socio-political conditions that dictate water planning, the biophysical conditions of the target catchments and level of environmental awareness among water users. Water problems are cross cutting issues that cannot be resolved by water professionals alone. They have become more complex and interconnected with social, economic, environmental and political issues at the local and global scales. In winding up this discussion let it be remembered that IWRM emerged as a noble model that negated the past characterized by sectoral approaches to water management but seems to have caused more confusion than expected. Meanwhile, we have to content with the model as this is the most fashionable water resources management model available.

\section{References}

Abdullah, K. (2005). Institutional Set-Up for Integrated Management of the Klang river Basin, Malaysia. In A. K. Biswas, O. Varis \& C. Tortajada (Eds.), Integrated Water Resources Management in South and South East Asia (pp. 178-205). Delhi: Oxford University Press.

Bandaragoda, D. J. (2002). Water - land linkages: A relatively neglected issue in integrated water resources management. Paper presented at the "SaciWATERs" workshop on "IWRM in South Asia: Global Theory, Emerging Practice and Local Needs" held in Colombo, Sri Lanka (20-22 December, 2002).

Bandaragoda, D. J., Mukand, M. S., \& Babel, S. (2010). Institutional Development for IWRM: an International Perspective. International Journal of River Basin Management, 8(3-4), 215-224. http://dx.doi.org/10.1080/15715124.2010.496707

Biswas, A. K. (2008). Integrated water resources management: Is it working? International Journal of Water Resources Development, 24(1), 5-22. http://dx.doi.org/10.1080/07900620701871718

Biswas, A. K. (2004). Integrated water resources management: a reassessment. Water Int., 29(2), 248-256. http://dx.doi.org/10.1080/02508060408691775

Bolding, A., Manzungu, E., \& van der Zaag, P. (1998). A realistic Approach to water Reform in Zimbabwe. In E. Manzungu \& P. van der Zaag (Eds.), Water for agriculture in Zimbabwe - Policy and management Options for the Small Holder Sector (pp. 219-224). Harare, Zimbabwe: University Of Zimbabwe Publications.

Butterworth, J., Warner, J., Moriarty, P., Smits, S., \& Batchelor, C. (2010). Finding practical approaches to Integrated Water Resources Management. Water Alternatives, 3(1), 68-81.

Cardwell, H. E., Cole, R. A., Cartwright, L. A., \& Martin, L. A. (2006). Integrated Water Resources Management: Definitions and Conceptual Musings. Journal of Contemporary Water Research and Education, 135, 8-18. http://dx.doi.org/10.1111/j.1936-704X.2006.mp135001002.x

Cilliers, P. (2005). Complexity, Deconstruction and Relativism. Theory, Culture and Society 2005 (SAGE, London, Thousand Oaks and New Delhi), 22(5), 255-267.

Cleaver, F. (1999). Paradoxes of participation: Questioning participatory approaches to development. Journal of International Development, 11(4), 597-612. http://dx.doi.org/10.1002/(SICI)1099-1328(199906)11:4<597::AID-JID610>3.0.CO;2-Q

Copi, M. (1986). Introduction to Logic. New York: MacMillan publishing co.

Edmunds, D., \& Wollenberg, E. (2001). A strategic approach to multistakeholder negotiations. Development and change, 32, 231-253. http://dx.doi.org/10.1111/1467-7660.00204

Gill, A. R. (1993). The Honeybee Pollination market as self organizing Emergent system. Armidale, University of New England. PHD: 367.

Global Water Partnership. (2000). Integrated Water Resources Management. Technical Background Paper No. 4. GWP Publishing. Retrieved from http://www.gwpforum.org/gwp/library/Tacno4.pdf

Global Water Partnership. (2003). GWP in Action.

Jonch-Clausen, T. (2004). Integrated Water Resources Management (IWRM) and Water Efficiency Plans by 2005: Why, What and How? Technical Committee Background Paper 10. Stockholm, Global Water Partnership.

Lankford, B., \& Hepworth, N. (2010). The cathedral and the bazaar: Monocentric and polycentric river basin management. Water Alternatives, 3(1). 
Latham, J. (2002). A review of the water reform process in Zimbabwe: The case of the Manyame Catchment Council. In E. Manzungu (Ed.), The process and dynamics of catchment management in Zimbabwe (pp. 21-43). Harare: Save Africa Publications.

Loris, A. (2008). The Limits of integrated water resources management: a case study of Brazil's Paraiba do Sul River Basin. Sustainability: Science, Practice, and Theory (Volume 4, Issue 2). Retrieved from http://ejournal.nbli.org

Matinenga, E. (1999). New Water Act for Zimbabwe? In E. Manzungu, A. Senjanje \& P. van der Zaag (Eds.), Water for agriculture in Zimbabwe -Policy and management Options for the Small Holder Sector (pp. 219-224). Harare, Zimbabwe: University of Zimbabwe publications.

Merrey, D. J. (2007). Balancing Equity, Productivity and Sustainability in a Water-Scarce River Basin: The Case of the Olifants River Basin in South Africa. Final Draft submitted to Comprehensive Assessment of Water Management in Agriculture and IWMI. Unpublished.

Merrey, D. J., Drechsel, P., Penning de Vries, P., \& Sally, H. (2005). Integrating "livelihoods" into integrated water resources management: Taking the integration paradigm to its logical next step for developing $\begin{array}{lllll}\text { countries. Regional and } & \text { Environmental }\end{array}$ http://dx.doi.org/10.1007/s10113-004-0088-5

Mohile, A. D. (2005). Integration in bits and parts: A case study for India. In A. K. Biswas, O. Varis \& C. Tortajada (Eds.), Integrated Water Resources Management in South and South East Asia (pp. 39-66). New Delhi: Oxford University Press.

Molle, F. (2006). Planning and Managing Water Resources at the River-Basin Level: Emergence and Evolution of a Concept. Comprehensive Assessment of Water Management in Agriculture Research Report 16. Colombo: IWMI.

Mollinga, P. P. (2006). IWRM in South Asia: A concept looking for a constituency. In P. P. Mollinga, A. Dixit, \& K. Athukorala (Eds.), Integrated water resources management in South Asia. Global theory, emerging practice and local needs (pp. 21-37). Water in South Asia Series No. 1. New Delhi: Sage.

Mtisi, S. (2011). Water reforms during the crisis and beyond: Understanding policy and political challenges of reforming the water sector in Zimbabwe. Working paper 33. Overseas Development Institute. Retrieved form http://www.odi.org.uk

Onta, R. I. (2005). Status of Integrated Water resources management in Nepal: an Overview. In A. K. Biswas, O. Varis \& C. Tortajada (Eds.), Status of Integrated Water Resources Management in South and South East Asia (pp. 148-177). New Delhi: Oxford University Press.

Placht, M. (2007). Integrated water resource management: Incorporating integration, equity, and efficiency to achieve sustainability. International Development, Environment and Sustainability, 3, 3. Retrieved from http://fletcher.tufts.edu/ierp/ideas/issue3.html

Rahaman, M. M., \& Varis, O. (2005). Integrated water Resources management: evolution, prospects and future challenges. Sustainability: Science, Practice, and Policy, 1, 1-8. Retrieved from http://ejournal.nbii.org

Shah, T., \& van Koppen, B. (2006). Is India ripe for integrated water resources management? Fitting water policy to national development context. Economic and Political Weekly, 41(31), 3413-3421.

Swatuk, L. A. (2002). New Water Architecture in Southern Africa: Reflections on Current Trends in the Light of Rio +10. International Affairs, 58, 1 .

Swatuk, L. A. (2005). Political challenges to implementing IWRM in Southern Africa. Physics and Chemistry of the Earth, 30(11-16), 872-880.

Syme, G. J., \& Nancarrow, B. E. (1999). Defining the components of fairness in the allocation of water to environmental and human uses. Journal of Environmental Management, 57(1), 51-70. http://dx.doi.org/10.1006/jema.1999.0282

Tortajada, C. (2005). Institutions for Integrated Water Resources Management in Latin America: Lessons for Asia. In A. K. Biswas, O. Varis \& C. Tortajada (Eds.), Integrated Water Resources Management in South and South-East Asia (pp. 297-318). Oxford: Oxford University Press.

U. N. (1992). Report on the International Conference on Water and the Environment. Dublin, Ireland.

Van Bueren, E. M., \& Klijin, E. H. (2003). Dealing with wicked problems in Networks: Analyzing an 
Environmental Debate from a network perspective. Public administration Research and Theory, 13(2), 193-212.

Van der Zaag, P. (2005). Integrated Water Resources Management: Relevant Concept or Irrelevant Buzzword: A Capacity Building and Research Agenda for Southern Africa. Physics and Chemistry of the Earth, 30, 867-871. http://dx.doi.org/10.1016/j.pce.2005.08.032

Vennix, J. A. M. (1996). Group model-building: Facilitating Team Learning Using System Dynamics. Chichester, John Wiley and Sons.

Warner, J., Butterworth, J., Wegerich, K., Mora Vallejo, A., Martinez, G., Gouet, C., \& Visscher, J. T. (2009). Corruption risks in water licensing with case studies from Chile and Kazakhstan. Swedish Water House Report No. 27. Stockholm: Stockholm International Water Institute.

Watson, N., Walker, G., \& Medd, W. (2007). Critical Perspectives on Integrated Water Management. The Geographical Journal, 173(4), 297-299. http://dx.doi.org/10.1111/j.1475-4959.2007.00259.x

\section{Copyrights}

Copyright for this article is retained by the author(s), with first publication rights granted to the journal.

This is an open-access article distributed under the terms and conditions of the Creative Commons Attribution license (http://creativecommons.org/licenses/by/3.0/). 